Oncology

\title{
Gene Expression of Vitamin D Metabolic Enzymes at Baseline and in Response to Vitamin D Treatment in Thyroid Cancer Cell Lines
}

\author{
Robert G. Bennett ${ }^{a, c}$ Shannon E. Wakeley ${ }^{a}$ Frederick G. Hamel $^{\text {a, c }}$

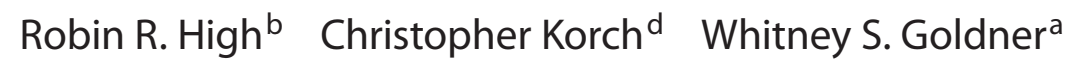 \\ a Division of Diabetes, Endocrinology and Metabolism, Department of Internal Medicine, and \\ ${ }^{b}$ Department of Biostatistics, College of Public Health, University of Nebraska Medical Center, and \\ 'Department of Medical Research, Veterans Affairs Medical Center, Omaha, Nebr., and \\ ${ }^{\mathrm{d}}$ DNA Sequencing and Analysis Core, University of Colorado Cancer Center, Aurora, Colo., USA
}

\section{Key Words}

Vitamin D · Thyroid cancer $\cdot$ CYP27A1 - CYP2R1 - CYP27B1 • CYP24A1

\begin{abstract}
The association between vitamin $\mathrm{D}$ and thyroid cancer is unclear. It is unknown if CYP27A1 or CYP2R1 are present in normal thyroid or cancer cells and there is limited information regarding response to treatment with vitamin D. SV40 immortalized follicular cells ( $\mathrm{N}$-thy) and six thyroid cancer cell lines were treated with $10 \mu \mathrm{M}$ vitamin $\mathrm{D}_{3}, 0.1 \mu \mathrm{M} 1,25(\mathrm{OH})_{2} \mathrm{D}_{3}$ or vehicle $\times 24$ h. CYP27A1, CYP2R1, CYP27B1 and CYP24A1 mRNA were measured using quantitative real-time-PCR before and after treatment. Cell proliferation was also evaluated in TPC1 and $\mathrm{C} 643$ cells after treatment with $\mathrm{D}_{3}, 25(\mathrm{OH}) \mathrm{D}_{3}$ and $1,25(\mathrm{OH})_{2} \mathrm{D}_{3}$. Baseline CYP27A1 and CYP27B1 mRNA were present in all cells, CYP2R1 was higher and CYP24A1 mRNA was lower in cancer cell lines versus $\mathrm{N}$-thy. TPC1 cells had increased CYP24A1 mRNA levels when treated with both $\mathrm{D}_{3}(3.49, \mathrm{p}<0.001)$ and $1,25(\mathrm{OH})_{2} \mathrm{D}_{3}(5.05, \mathrm{p}<0.001)$. C643 cells showed increased CYP24A1 mRNA expression when treated with $1,25(\mathrm{OH})_{2} \mathrm{D}_{3}(5.36, \mathrm{p}<0.001) . \mathrm{D}_{3}, 25(\mathrm{OH}) \mathrm{D}_{3}$ and $1,25(\mathrm{OH})_{2} \mathrm{D}_{3}$ all significantly decreased cell proliferation in
\end{abstract}

TPC1 and C643 cells. Overall, both cancerous and N-thy cell lines express CYP27A1 and CYP2R1 in addition to CYP27B1, establishing the potential to metabolize $D_{3}$ to $1,25(\mathrm{OH})_{2} \mathrm{D}_{3}$. Additionally, vitamin $\mathrm{D}_{3}, 25(\mathrm{OH}) \mathrm{D}_{3}$ and $1,25(\mathrm{OH})_{2} \mathrm{D}_{3}$ all had an antiproliferative effect on two thyroid cancer cell lines.

Copyright $\odot 2012$ S. Karger AG, Basel

\section{Background}

Thyroid cancer is common and on the rise [1]. The most common forms of differentiated thyroid cancer are classified histologically into papillary, follicular and anaplastic. We now know that within each classification there are distinct mutations that confer different characteristics, information that may prove helpful in determining behavior and aggressiveness of the tumor and potential individualized treatment strategies [2]. We are in search of novel risk factors and treatment strategies for thyroid cancer.

Vitamin D deficiency has recently been implicated in the pathogenesis of many cancers, including prostate, breast, pancreatic, colon and squamous cell cancer [3]. It is known that these tissues express vitamin $\mathrm{D}$ receptors

\section{KARGER}

Fax +4161306 1234

E-Mail karger@karger.ch

www.karger.com
(C) 2012 S. Karger AG, Basel

$0030-2414 / 12 / 0835-0264 \$ 38.00 / 0$

Accessible online at:

www.karger.com/ocl
Whitney Goldner, MD

University of Nebraska Medical Center, Department of Internal Medicine

Division of Diabetes, Endocrinology and Metabolism

984120 Nebraska Medical Center, Omaha, NE 68198-4120 (USA)

Tel. +1 402559 3579, E-Mail wgoldner@unmc.edu 
(VDRs) and that vitamin $\mathrm{D}$, specifically $1,25(\mathrm{OH})_{2} \mathrm{D}_{3}$, has several potential therapeutic properties in patients suffering from these cancers. Mechanisms of $1,25(\mathrm{OH})_{2} \mathrm{D}_{3}$ action in cancer include inhibition of proliferation associated with cell cycle arrest, induction of differentiation, reduction of both invasiveness and angiogenesis, and enhanced apoptosis [4].

Formation of $1,25(\mathrm{OH})_{2} \mathrm{D}_{3}$ involves several enzymatic steps. First, cholecalciferol is ingested via dietary sources or formed by the photoconversion of 7-dehydrocholesterol in the skin. It is then metabolized to $25(\mathrm{OH}) \mathrm{D}_{3}$ in the liver by either the mitochondrial enzyme vitamin $\mathrm{D}$ 25-hydroxylase (CYP27A1) or the microsomal enzyme vitamin D 25-hydroxylase (CYP2R1) [5-7]. CYP27A1 appears to preferentially respond to $\mathrm{D}_{3}$, whereas CYP2R1 appears to respond equally to $\mathrm{D}_{2}$ and $\mathrm{D}_{3}$ [7]. Cheng et al. [6] reported a case of $25 \mathrm{OHD}_{3}$ deficiency to have a mutation in the CYP2R1 gene on chromosome 11, suggesting that CYP2R1 may be the more biologically relevant vitamin D 25-hydroxylase in humans. $25(\mathrm{OH}) \mathrm{D}_{3}$ is subsequently converted into $1,25(\mathrm{OH})_{2} \mathrm{D}_{3}$ via $1 \alpha$-hydroxylase (CYP27B1). The active form of vitamin $\mathrm{D}, 1,25(\mathrm{OH})_{2} \mathrm{D}_{3}$ exerts its biological effects by binding to the VDR and forming a heterodimer with the retinoid $\mathrm{X}$ receptor. The enzyme24-hydroxylase(CYP24A1) converts $1,25(\mathrm{OH})_{2} \mathrm{D}_{3}$ to the metabolites $1 \alpha 24,25(\mathrm{OH})_{2} \mathrm{D}_{3}$ and $24,25(\mathrm{OH})_{2} \mathrm{D}_{3}$ [3].

It is already known that thyroid and thyroid cancer cells express VDRs and CYP27B1 [8, 9]. However, VDR expression is variable in distinct thyroid cancer cell lines (C643, BCPAP, Hth7, Hth74, K1, KAT18, SW1736 and TPC1), and the presence of VDR does not predict reduction in cell viability in response to treatment with calcitriol $\left[1,25(\mathrm{OH})_{2} \mathrm{D}_{3}\right]$ or a noncalcemic vitamin $\mathrm{D}$ analog [8]. One study showed that in vitro administration of calcitriol increased expression of the tumor suppressor protein p27 and decreased cell proliferation in the WRO follicular thyroid carcinoma cell line [10]. Increased expression of p27 also correlated with decreased metastatic spread [10]. The same group went on to demonstrate that in vivo calcitriol administration could restore p27 accumulation in thyroid carcinoma cells, an effect associated with appreciably enhanced cellular differentiation, reduction in tumor burden and prevention of metastatic growth [10]. It is unknown whether CYP27A1 or CYP2R1 is present in either normal or cancerous thyroid cells. If CYP27A1 and/or CYP2R1 are present in noncancerous and/or cancerous thyroid cells, then conversion of $\mathrm{D}_{3}$ to $25 \mathrm{OHD}_{3}$ could potentially occur in these cells. Then production of $1,25(\mathrm{OH})_{2} \mathrm{D}_{3}$ could occur in the presence of
CYP27B1, which has already been reported in thyroid cells. In this study, we evaluated baseline gene expression of CYP27A1, CYP2R1, CYP27B1 and CYP24A1 and the effect of treatment with cholecalciferol $\left(\mathrm{D}_{3}\right)$ and $1,25(\mathrm{OH})_{2} \mathrm{D}_{3}$ on gene expression in both SV40-immortalized follicular thyroid cells (N-thy) and six distinct thyroid cancer cells lines. We also evaluated the proliferation in all lines after treatment with $\mathrm{D}_{3}, 25(\mathrm{OH}) \mathrm{D}_{3}$ and $1,25(\mathrm{OH})_{2} \mathrm{D}_{3}$.

\section{Materials and Methods}

\section{Cell Culture}

Confirmed thyroid cancer cell lines [11] were obtained from Dr. Rebecca Schweppe, University of Colorado, with permission from the following researchers: BCPAP: female papillary thyroid cancer BRAF(V600E) mutation and KTC-1: male papillary thyroid cancer BRAF(V600E) mutation, from Dr. Junichi Kurebayashi; TPC1: p18 papillary thyroid cancer RET/PTC1 mutation, from Dr. Rebecca Schweppe; FTC133: p15 follicular thyroid cancer, from Dr. Electron Kebebew; Hth7: p90 anaplastic thyroid cancer BRAF WT and C643: p16 male anaplastic thyroid cancer HRAS (G13R) mutation, from Dr. Nils-Erik Heldin; N-thy: SV40immortalized follicular cell line was purchased from the European Collection of Animal Cell Culture, Salisbury, UK, by Dr. Robert Anderson, Creighton University, Omaha, Nebr., USA, and we obtained these cells from him with permission. N-thy, BPCAP, TPC1, C643 and Hth7 cells were grown in RPMI /10\% FBS $+0.1 \%$ gentamicin, and FTC133 and KTC-1 cells were grown in DMEM/ Ham's F12/10\% FBS + 0.1\% gentamicin. Cell lines were grown at $37^{\circ} \mathrm{C}$ with $5 \% \mathrm{CO}_{2}$ in a humidified environment. To avoid cross contamination, each cell line was cultured separately with a separate bottle of media in a sterile tissue culture hood.

\section{STR Profiling}

Because recent studies have shown that certain thyroid cancer cell lines have been of nonthyroid origin [11], we performed STR (short tandem repeat) profiling to verify that the cell lines used in our study were of stated origin. DNA extraction was performed using Gentra Puregene Cell Kit, and DNA quantity was determined by measurement of absorbance at 260 and $280 \mathrm{~nm}$ using a Nanodrop spectrophotometer (Thermo Scientific) and by ethidium bromide staining on agarose gels. STR profiling was performed using the Applied Biosystems AmpF/STR Identifiler PCR Amplification kit (P/N 4322288) and results were cross referenced with cells proven to be unique thyroid cancer cell lines [11].

\section{Gene Expression}

CYP27A1, CYP2R1, CYP27B1, CYP24A1 and TATA binding protein (TBP) gene expression was determined in each cell line. Total RNA was extracted using the Purelink kit (Invitrogen), treated with RNase-free DNase, and then quantified using the Ribogreen assay (Invitrogen). The integrity and purity of the RNA was verified by visualization of rRNA on agarose gels. Equal amounts of RNA $(2 \mu \mathrm{g})$ were converted to cDNA using TaqMan High Capacity Reverse Transcriptase (Applied Biosystems), in a total reaction volume of $20 \mu \mathrm{l}$. For real-time PCR analysis, the 
cDNA was diluted in an equal volume of nuclease-free water, and $1 \mu \mathrm{l}$ of the diluted cDNA was amplified using TaqMan Master Mix and predetermined TaqMan Gene Expression Assay primer and probe sets (Applied Biosystems), in a reaction volume of 50 $\mu l$, in triplicate wells. These intron-spanning primers have been validated by the manufacturer to possess amplification efficiencies of $100 \pm 10 \%$ under the assay conditions. The real-time PCR reaction was performed using an ABI 7300 instrument. The gene expression assays used included CYP24A1 (assay Hs00167999_ $\mathrm{m} 1$, exon boundary 7-8 and amplicon length 123), CYP27A1 (assay Hs01017992_g1, exon boundary 8-9 and amplicon length 68), CYP2R1 (assay Hs01379776_m1, exon boundary 4-5 and amplicon length 79), CYP27B1 (assay Hs00168017_m1, exon boundary 8-9 and amplicon length 60) and TBP (assay Hs99999910_m1, exon boundary 6-6, amplicon length 127). The expression level of TBP within each cell line did not change with treatment. The CYP24A1, CYP2R1, CYP27A1 and CYP27B1 levels were normalized to that of TBP within each cell line, and relative gene expression was determined using the relative $\mathrm{C}_{\mathrm{T}}$ method.

\section{Vitamin D Treatment}

Experiments were performed in triplicate wells per condition and repeated three times (two times for CYP2R1). For gene expression assays, cell lines were treated with either vitamin $\mathrm{D}_{3}$ or $1,25(\mathrm{OH})_{2} \mathrm{D}_{3}$ for $24 \mathrm{~h}$. Concentrations of vitamin $\mathrm{D}$ were selected based on previous studies [12-14]. All cell lines were treated with $10^{-5} \mathrm{M}$ vitamin $\mathrm{D}_{3}, 10^{-7} \mathrm{M} 1,25(\mathrm{OH})_{2} \mathrm{D}_{3}$ or vehicle ( $0.1 \%$ ethanol). At the end of treatment, total cellular RNA was extracted as described above. For cell proliferation experiments, cells were treated with vitamin $\mathrm{D}_{3}(0.1-20.0 \mu \mathrm{M}), 25(\mathrm{OH}) \mathrm{D}_{3}(1.0 \mathrm{nM}-10 \mu \mathrm{M})$, $1,25(\mathrm{OH})_{2} \mathrm{D}_{3}(1.0 \mathrm{nM}-10 \mu \mathrm{M})$ or vehicle $(0.1 \%$ ethanol) for $72 \mathrm{~h}$.

\section{DNA Synthesis Assay}

Cell proliferation was assessed by measurement of thymidine incorporation into DNA as described [15]. Briefly, cells were plated into triplicate wells of 24 -well plates at $10^{4}$ cells per well in growth medium containing serum. After $24 \mathrm{~h}$, the medium was changed to growth medium containing $\mathrm{D}_{3}, 25(\mathrm{OH}) \mathrm{D}_{3}$, $1,25(\mathrm{OH})_{2} \mathrm{D}_{3}$ or ethanol, and cells were incubated for $72 \mathrm{~h}$. The medium was again changed to growth medium containing $\mathrm{D}_{3}$, $1,25(\mathrm{OH})_{2} \mathrm{D}_{3}$ or ethanol, and cells were incubated for $8 \mathrm{~h}$. For the last $4 \mathrm{~h}$ of incubation, $0.1 \mu \mathrm{Ci} / \mathrm{ml}$ [methyl- ${ }^{3} \mathrm{H}$ ]-thymidine (PerkinElmer) was added to the medium. After washing, DNA was precipitated with ice-cold $10 \%$ trichloroacetic acid, then solubilized in $0.1 \mathrm{~N} \mathrm{NaOH} / 0.1 \%$ sodium dodecyl sulfate. The extracted DNA was mixed with scintillation fluid (Optima Gold XR, Perkin-Elmer) and counted in a liquid scintillation counter.

\section{Statistical Analysis}

The design of the study includes 3 experimental factors: 'sample' with 7 levels, 'treatment' with 3 levels and 'detector' with 5 levels for a total of 105 factor combinations. Three replications for each combination of factors were made [ 63 observations for the 4 levels of detector $(7 \times 3 \times 3)$ with extra replications for CYP2R1 giving this level 126 observations], providing a total sample size of $n=378$ observations. Because of the extreme skewness of the data (all positive values), a log transformation was first applied. A three-way factorial ANOVA with unique residual variances for each level of sample was applied to these log-transformed data. The three-way interaction was determined to be significant $(\mathrm{p}<$
0.001). The objective of the study was to test the equality of the differences in least square means of the transformed data from 4 levels of detector (CYP27A1, CYP2R1, CYP27B1 and CYP24A1) with the reference level as TBP. Because both types of vitamin D (treatment) were dissolved in ethanol, the effect ethanol had on mRNA expression was removed during analysis after treatment with both $\mathrm{D}_{3}$ and $1,25(\mathrm{OH})_{2} \mathrm{D}_{3}$ to appropriately measure the effect that vitamin D treatment had on CYP27A1, CYP2R1, CYP27B1 and CYP24A1 mRNA expression. These differences across six levels of sample (BCPAP, KTC, TPC1, FTC133, C643 and Hth7) were then compared to the same differences computed for N-thy. Since multiple comparisons in factor levels were made, adjusted confidence intervals of these differences of differences were computed. Contrasts with corresponding adjusted $p$ values $<0.05$ indicate a significant difference exists. The data were analyzed with PROC GLIMMIX [SAS STAT software for Windows, Version 9.2 (2008), Cary, N.C., USA]. For cell proliferation studies, curve-fitting and ANOVA analysis was performed using GraphPad Prism5 (GraphPad, LaJolla, Calif., USA).

\section{Results}

\section{Baseline Levels of CYP27A1, CYP2R1, CYP27B1 and CYP24A1}

We detected gene expression of both CYP27A1 and CYP2R1 in N-thy cells as well as in six distinct thyroid cancer cell lines (fig. 1). Gene expression of CYP27A1 was variable amongst different thyroid cancer cell types. mRNA levels of CYP27A1 were significantly higher in BCPAP papillary and C643 anaplastic cells compared to $\mathrm{N}$-thy (1.44 and 3.63, respectively, vs. $1.00, \mathrm{p}<0.05$ ), whereas mRNA levels of CYP27A1 in TPC1 papillary, FTC133 follicular and Hth7 anaplastic were significantly lower $(0.12,0.05$ and 0.16 , respectively, vs. $1.00, \mathrm{p}<0.05)$. Levels were not statistically different in KTC-1 papillary cells compared to $\mathrm{N}$-thy. In contrast, only mRNA levels of CYP2R1 in Hth7 cells were significantly higher than in $\mathrm{N}$-thy (3.67 vs. $1.00, \mathrm{p}<0.05)$. CYP27B1 mRNA expression was significantly higher in TPC1 papillary, BCPAP papillary, FTC133 follicular and Hth7 anaplastic cells when compared to N-thy cells (4.11, 1.47, 1.15 and 2.79 , respectively, vs. 1.0, p $<0.05$; fig. 1). Expression of CYP27B1 mRNA was significantly lower in KTC-1 papillary and C643 anaplastic cells compared to N-thy cells $(0.23,0.24$, respectively, vs. $1.0, \mathrm{p}<0.05)$. Interestingly, CYP24A1 levels were significantly decreased in all thyroid cancer cell lines in comparison to $\mathrm{N}$-thy cells (fig. 1). In TPC1 papillary, KTC-1 papillary, BCPAP papillary, FTC133 follicular, C643 anaplastic and Hth7 anaplastic cells, CYP24A1 expression was $0.002,0.70,0.55,0.43$ and 0.01 , respectively, vs. 1.00 in the $\mathrm{N}$-thy cells, $\mathrm{p}<0.05$. 
Fig. 1. Baseline levels of CYP27A1, CYP2R1, CYP27B1 and CYP24A1 within distinct thyroid cancer cell lines as compared to SV40 immortalized follicular cells (N-thy). While CYP27A1 and CYP27B1 expression is variable, CYP2R1 expression is increased in all thyroid cancer cell lines, but only reaches statistical significance in the Hth7 cells. CYP24A1 expression is decreased in all thyroid cancer cell lines when compared to N-thy. Results are reported as difference in the log mean (with 95\% CI) expression of each cancer cell line relative to that in $\mathrm{N}$-thy. ${ }^{*} \mathrm{p}<0.05$.

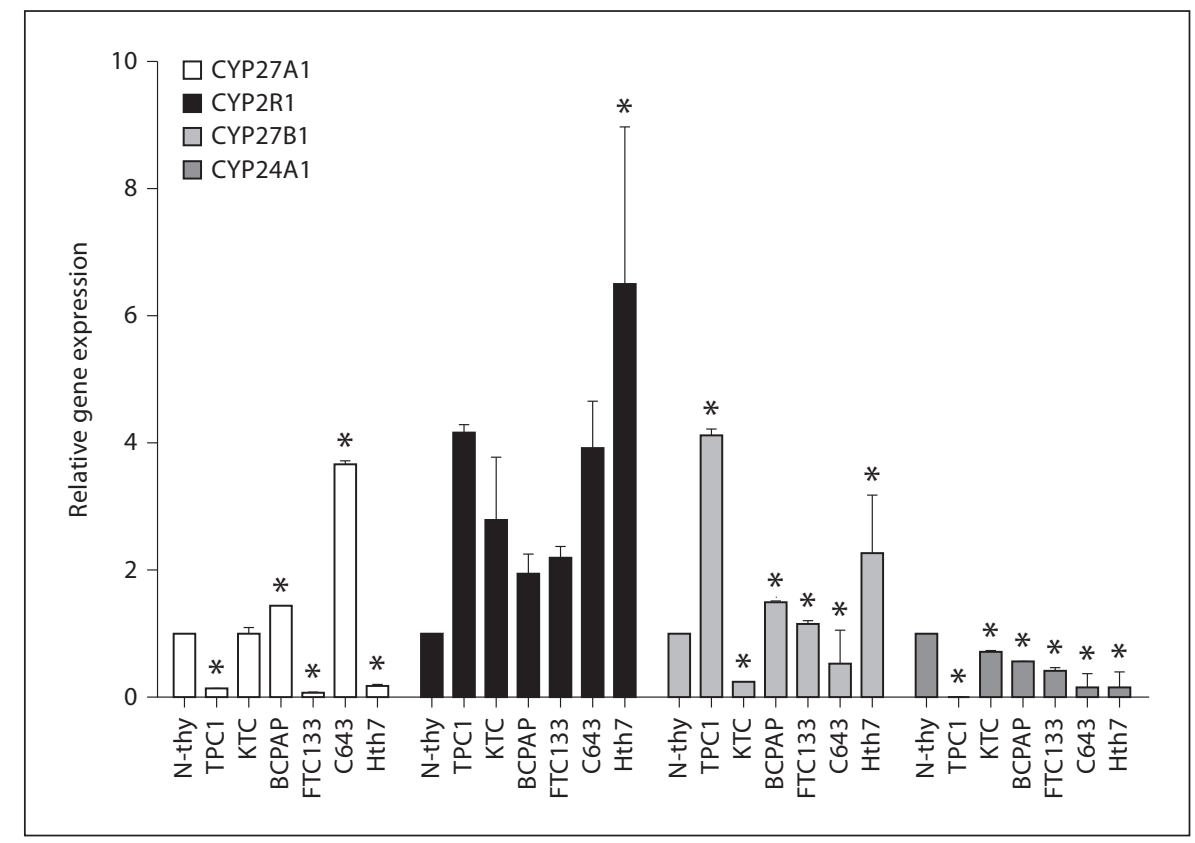

Effect of Treatment with Vitamin $D_{3}$ on Gene Expression of CYP27A1, CYP2R1, CYP27B1 and CYP24A1

The effect of vitamin $\mathrm{D}_{3}$ treatment on CYP27A1, CYP2R1, CYP27B1 and CYP24A1 mRNA expression levels was measured (fig. 2). Treatment with vitamin $\mathrm{D}_{3}$ did not result in a statistically significant change in their levels in the $\mathrm{N}$-thy cells. The response for each cell line was compared to the changes observed in the $\mathrm{N}$-thy cell line. CYP27A1, CYP2R1 and CYP27B1 mRNA levels were not statistically different in any cell lines treated with vitamin $\mathrm{D}_{3}$. In contrast, treatment with vitamin $\mathrm{D}_{3}$ significantly increased expression of CYP24A1 mRNA in TPC1 papillary cells $(3.49, \mathrm{p}=0.001)$, but did not produce statistically significant changes in the other cell lines: BCPAP papillary (0.58, $\mathrm{p}=0.90)$, C643 anaplastic (2.18, $\mathrm{p}=0.11)$, FTC133 follicular $(-0.63, \mathrm{p}=0.85)$, Hth7 anaplastic $(-0.04, \mathrm{p}=0.62)$ and KTC-1 papillary $(0.19, \mathrm{p}=1.00)$.

\section{Effect of Treatment with $1,25(\mathrm{OH})_{2} \mathrm{D}_{3}$ on Gene Expression of CYP27A1, CYP2R1, CYP27B1 and CYP24A1}

After treating all cell lines with $1,25(\mathrm{OH})_{2} \mathrm{D}_{3}$, the CYP27A1, CYP2R1, CYP27B1 and CYP24A1 mRNA expression levels were measured and the response for each cell line was compared to changes in the $\mathrm{N}$-thy cell line (fig. 3). CYP27A1, CYP2R1 and CYP27B1 mRNA expres- sion levels were not statistically different in any cell lines. In contrast, $1,25(\mathrm{OH})_{2} \mathrm{D}_{3}$ treatment produced statistically significant increases in CYP24A1 mRNA expression in TPC1 papillary and C643 anaplastic cell lines (5.05 and 5.36 , respectively, $\mathrm{p}<0.001$ ). There were no statistically significant changes in CYP24A1 mRNA expression in KTC-1 papillary $(0.33, \mathrm{p}=0.99)$, BCPAP papillary $(-0.51$, $\mathrm{p}=0.94)$, FTC133 follicular $(-0.72, \mathrm{p}=0.76)$ or Hth7 anaplastic $(-0.23, \mathrm{p}=0.99)$ when compared to the change in the $\mathrm{N}$-thy cell line.

Effect of $D_{3}, 25(\mathrm{OH}) D_{3}$ and $1,25(\mathrm{OH})_{2} D_{3}$ on

Proliferation of TPC1 and C643 Cells

Thetwo cell lines that responded to $\mathrm{D}_{3}$ and $1,25(\mathrm{OH})_{2} \mathrm{D}_{3}$ (TPC1 and C643) were tested to determine the effect on cell proliferation. Cells were treated with various concentrations of $\mathrm{D}_{3}, 25(\mathrm{OH}) \mathrm{D}_{3}$ or $1,25(\mathrm{OH})_{2} \mathrm{D}_{3}$, and ${ }^{3} \mathrm{H}$-thymidine uptake was measured to determine the rate of DNA synthesis. Both cell lines responded to $1,25(\mathrm{OH})_{2} \mathrm{D}_{3}$ in a concentration-dependent manner (fig. 4). Interestingly, TPC1 cells displayed much greater sensitivity to $1,25(\mathrm{OH})_{2} \mathrm{D}_{3}$ than C643 cells $\left(\mathrm{IC}_{50} 0.019\right.$ vs. $3.7 \mu \mathrm{M}$, respectively). Conversely, TPC1 cells were less sensitive to $25(\mathrm{OH}) \mathrm{D}_{3}$ than $\mathrm{C} 643$ cells $\left(\mathrm{IC}_{50} 8.4\right.$ vs. $2.8 \mu \mathrm{M}$, respectively). Treatment with $\mathrm{D}_{3}$ resulted in similar inhibition of proliferation in both cell lines ( $\mathrm{IC}_{50} 16.8 \mu \mathrm{M}$ for TPC1 vs. $13.8 \mu \mathrm{M}$ for C643). 


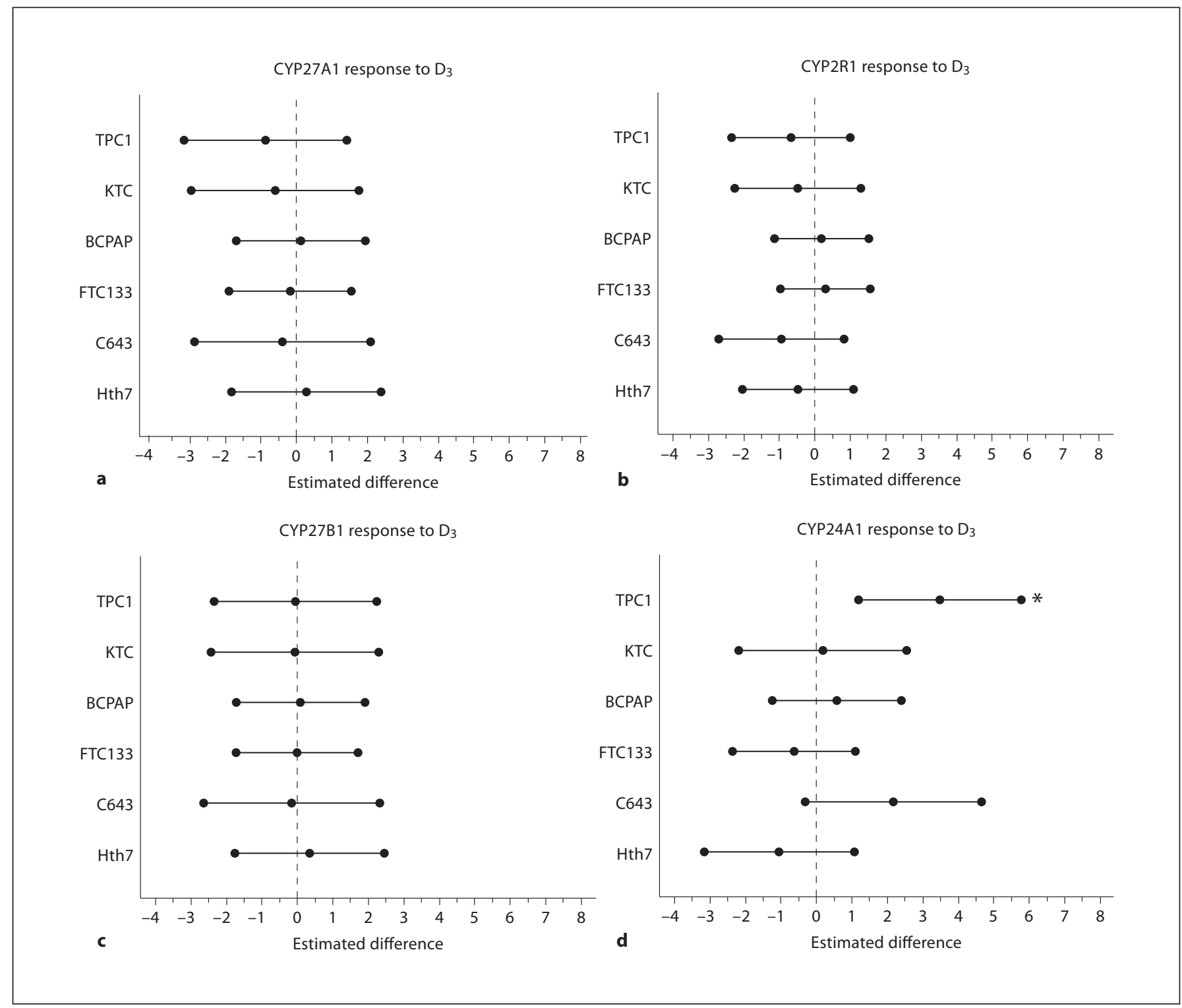

Fig. 2. $\mathrm{D}_{3}$ effect on CYP27A1 (a), CYP2R1 (b), CYP27B1 (c) and CYP24A1 (d) expression in distinct thyroid cancer cell lines. The response for each cell line was compared to the change in SV40 immortalized follicular cell line (N-thy). CYP27A1, CYP2R1 and
CYP27B1 expression was unchanged. CYP24A1 expression was increased in TPC1 papillary. Results are reported as difference in the log mean (with 95\% CI) expression of each cancer cell line relative to that in $\mathrm{N}$-thy. ${ }^{*} \mathrm{p}<0.05$.

\section{Discussion}

Even though CYP27A1 and CYP2R1 are most well known for their activity in the liver, we report the presence of CYP27A1 and CYP2R1 in the SV40 immortalized follicular cell line and six distinct thyroid cancer cell lines. It is already known that thyroid cells have VDRs and CYP27B1 and CYP24A1 gene expression [8]. Addi- tionally, Sharma et al. $[8,16]$ have already reported VDR expression for TPC1, C643, Hth7, BCPAP and KTC1 thyroid cancer cell lines, and all cells have VDR expression with Hth7 having the least. The presence of CYP27A1 and CYP2R1 gene expression indicates there is potential for thyroidcells to generate activevitamin $\mathrm{D}\left[1,25(\mathrm{OH})_{2} \mathrm{D}_{3}\right]$ in the presence of adequate levels of $\mathrm{D}_{3}$. 


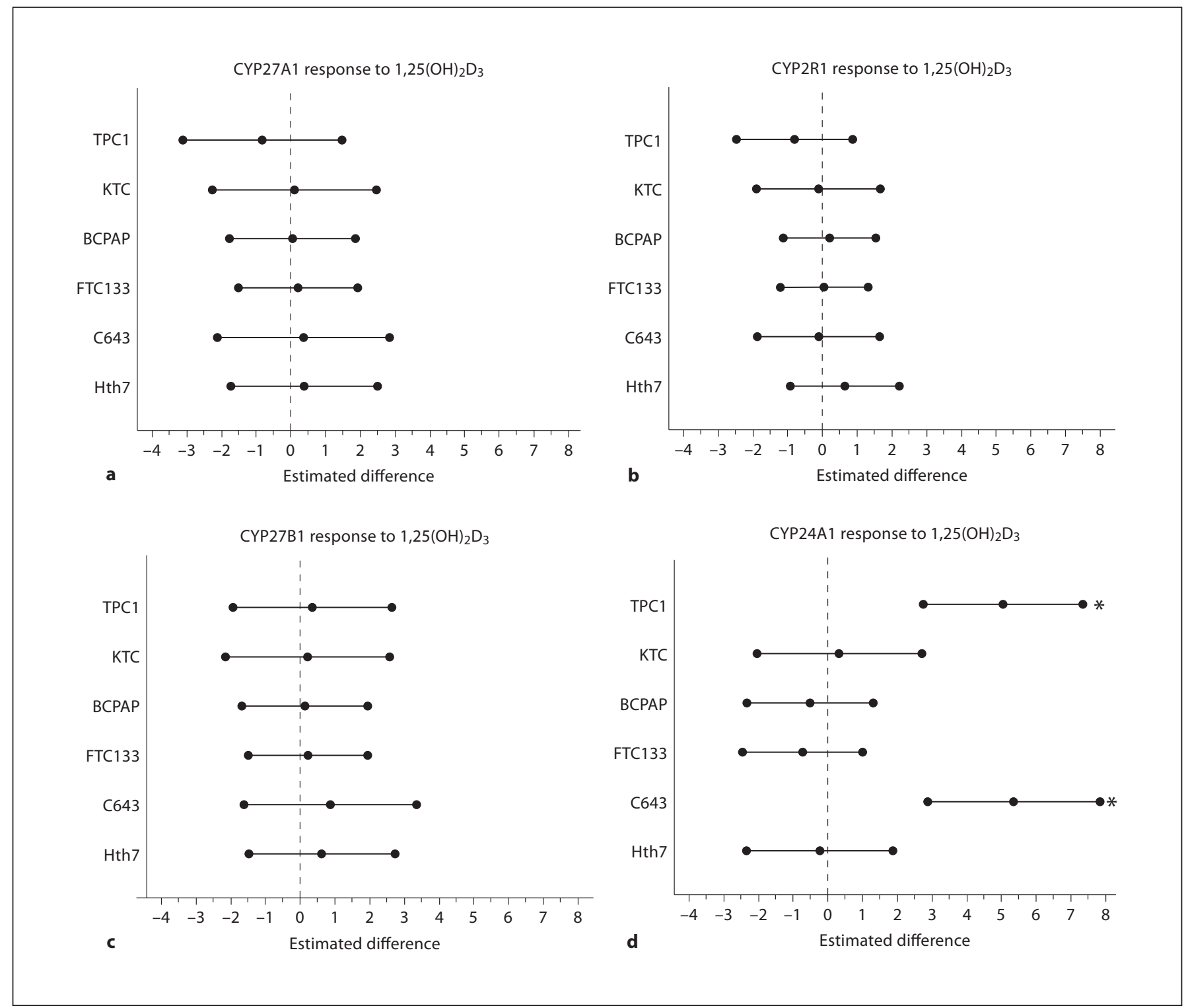

Fig. 3. $1,25(\mathrm{OH})_{2} \mathrm{D}_{3}$ effect on CYP27A1 (a), CYP2R1 (b), CYP27B1 (c) and CYP24A1 (d) expression in distinct thyroid cancer cell lines. The response for each cell line was compared to the change in the SV40 immortalized follicular cell line (N-thy). CYP27A1,
CYP2R1 and CYP27B1 expression was unchanged. CYP24A1 expression was increased in TPC1 papillary and C643 anaplastic. Results are reported as difference in the log mean (with 95\% CI) expression of each cancer cell line relative to that in $\mathrm{N}$-thy. ${ }^{*} \mathrm{p}<0.05$.
The regulation of these enzymes is poorly understood and it is unknown if they are directly regulated by vitamin $\mathrm{D}_{3}$ or $1,25(\mathrm{OH})_{2} \mathrm{D}_{3}$ [5]. Additionally, the regulation of CYP27A1 or CYP2R1 may not be critical in determining the cell's ability to generate active vitamin D. Given the lack of gene expression response of either enzyme after treatment with $\mathrm{D}_{3}$ and $1,25(\mathrm{OH})_{2} \mathrm{D}_{3}$, it will be important to measure active enzyme and protein expression of
$25 \mathrm{OHD}_{3}$ and $1,25(\mathrm{OH})_{2} \mathrm{D}_{3}$ before and after treatment with $\mathrm{D}_{3}$ both in vitro and in vivo to evaluate CYP27A1 and CYP2R1's true activity, especially since CYP2R1 has been reported to be the more biologically active enzyme in humans [6].

When evaluating CYP27B1, none of the cell lines had a differential response in gene expression after treatment with $\mathrm{D}_{3}$, which may not be wholly unexpected since 


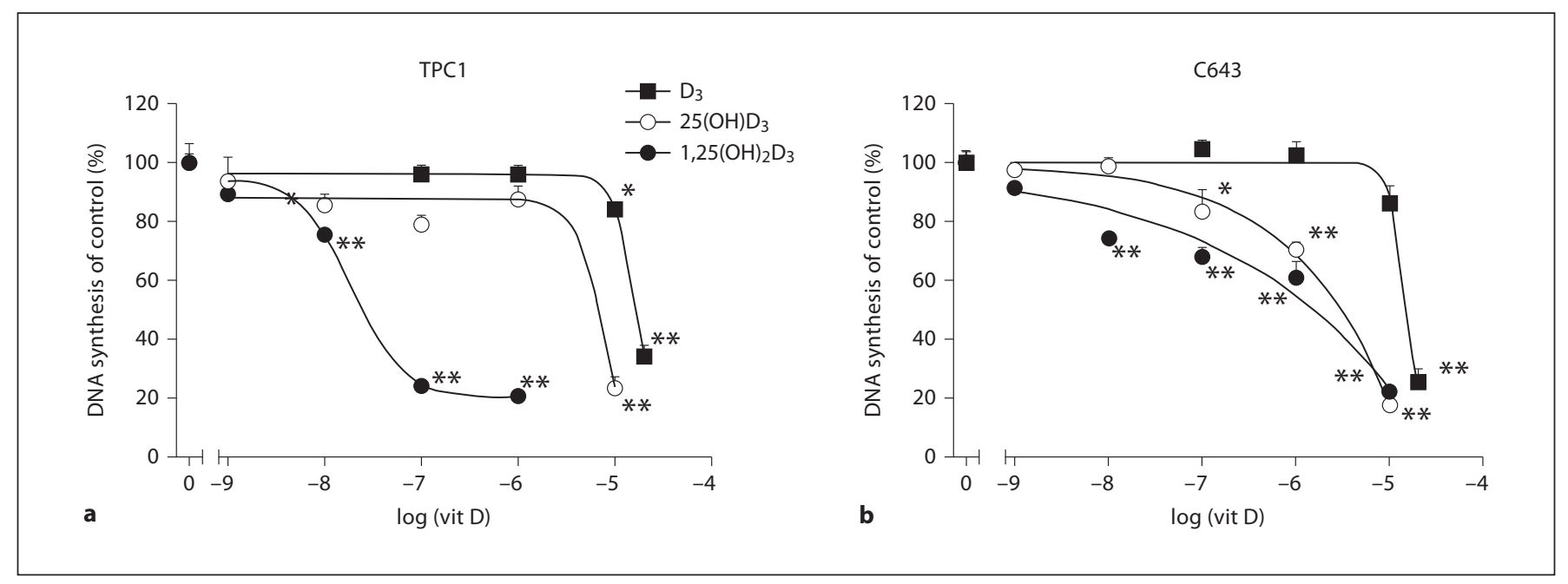

Fig. 4. Cell proliferation rate in THP1 (a) and C643 (b) cells. Cells were treated with $\mathrm{D}_{3}, 25(\mathrm{OH}) \mathrm{D}_{3}, 1,25(\mathrm{OH})_{2} \mathrm{D}_{3}$ or vehicle (ethanol), and DNA synthesis was measured by incorporation of [methyl-3H]-thymidine. The cell proliferation rate was decreased in both cell lines by $1,25(\mathrm{OH})_{2} \mathrm{D}_{3}$ in a concentration- dependent manner, while $\mathrm{D}_{3}$ inhibited proliferation at higher concentrations. Data are expressed as the mean \% thymidine incorporation compared to ethanol treatment, mean \pm SEM. ${ }^{*} \mathrm{p}<0.05 ;{ }^{* *} \mathrm{p}<0.01$.
CYP27B1 is regulated through negative feedback by $1,25(\mathrm{OH})_{2} \mathrm{D}_{3}$ in the kidney; however, regulation of these genes in extra-renal sites is poorly understood [5]. It may also indicate that there was not significant $1,25(\mathrm{OH})_{2} \mathrm{D}_{3}$ production after treatment with $\mathrm{D}_{3}$ since the expected result would be a decrease in the CYP27B1 gene expression. However, there was also no differential response in CYP27B1 gene expression when treated with $1,25(\mathrm{OH})_{2} \mathrm{D}_{3}$, suggesting it may not be regulated by negative feedback in the thyroid.

Baseline CYP24A1 gene expression varied in different cell types, but was consistently lower in all cancer cell lines compared with immortalized follicular thyroid cells. The lowest baseline CYP24A1 expression was in the TPC1 cells, followed by the C643 cells as the next lowest. After treatment with $1,25(\mathrm{OH})_{2} \mathrm{D}_{3}$, however, the cells lines with the lowest baseline values of CYP24A1 had the greatest increase in CYP24A1 mRNA. It is known that CYP24A1 gene expression is directly regulated by $1,25(\mathrm{OH})_{2} \mathrm{D}_{3}$, so it is logical that expression would increase with treatment with $1,25(\mathrm{OH})_{2} \mathrm{D}_{3}$ and potentially $\mathrm{D}_{3}$ (if there was adequate conversion to $25 \mathrm{OHD}_{3}$ ). CYP24A1 gene expression is also regulated in response to activation of the VDR [3] and can be variable depending on whether the cells are relatively sensitive or resistant to vitamin D [8]. TPC1 papillary thyroid cancer cells had nearly undetectable baseline levels of CYP24A1, but showed a significant increase in gene expression after treatment with both $\mathrm{D}_{3}$ and $1,25(\mathrm{OH})_{2} \mathrm{D}_{3}$. Additionally, there was increased CYP24A1 mRNA expression in C643 anaplastic cells when treated with vitamin $\mathrm{D}_{3}$ and $1,25(\mathrm{OH})_{2} \mathrm{D}_{3}$; however, it was not significant in the vitamin $\mathrm{D}_{3}$ treated group. Interestingly, C643 cells had the next lowest baseline CYP24A1 gene expression at baseline. These results are similar to those seen by Sharma et al. [8], who reported that the TPC1 and C643 thyroid cancer cells are sensitive to VDR activation and have lower baseline levels of CYP24A1 and CYP27B1 as compared with resistant thyroid cancer cell lines. They also reported that thyroid cancer cells with the FF FokI variant of the VDR were relatively resistant to the effects of $1,25(\mathrm{OH})_{2} \mathrm{D}_{3}$. It is unknown whether one can overcome the relative resistance to vitamin $\mathrm{D}$ in specific cell lines by administering higher doses of either $\mathrm{D}_{3}$ or $1,25(\mathrm{OH})_{2} \mathrm{D}_{3}$.

The findings that thyroid cancer cells express CYP27A1, CYP2R1 and CYP27B1 suggest that they may have the capacity to convert $\mathrm{D}_{3}$ to $1,25(\mathrm{OH})_{2} \mathrm{D}_{3}$, and that vitamin $\mathrm{D}$ (in any form) might decrease proliferation of these cells. Indeed, $\mathrm{D}_{3}$ did significantly decrease proliferation of TPC1 and C643 cells, although at much higher concentrations than $1,25(\mathrm{OH})_{2} \mathrm{D}_{3}$. Since it is unknown how much $\mathrm{D}_{3}$ circulates before conversion in the liver, it is difficult to compare this to a clinical circulating concentration of $\mathrm{D}_{3}$. At the highest concentration $(20 \mu \mathrm{M})$, 
the inhibition of cell growth was equivalent to that attained by $10 \mathrm{nM} 1,25(\mathrm{OH})_{2} \mathrm{D}_{3}$ in both cell lines, even though the TPC1 cells were considerably more sensitive to $1,25(\mathrm{OH})_{2} \mathrm{D}_{3}$. The ability of $25(\mathrm{OH}) \mathrm{D}_{3}$ to inhibit cell proliferation was intermediate between that of $\mathrm{D}_{3}$ and $1,25(\mathrm{OH})_{2} \mathrm{D}_{3}$.

Clinically, toxic levels of circulating $25(\mathrm{OH}) \mathrm{D}_{3}$ are reported at $150 \mathrm{ng} / \mathrm{ml}(375 \mathrm{nM})$. In this study, the concentrations that resulted in a reduction in cell proliferation are in that range $(10-1,000 \mathrm{nM})$. Hence, using vitamin $\mathrm{D}_{3}$ or $25(\mathrm{OH}) \mathrm{D}_{3}$ to achieve these circulating levels may not be clinically applicable. We saw equivalent inhibition of proliferation at approximately $10 \mu \mathrm{M}\left(10^{-5} \mathrm{M}\right)$ for $\mathrm{D}_{3}$ and $25(\mathrm{OH}) \mathrm{D}_{3}$, suggesting these effects cannot be explained by binding kinetics alone. It is not clear whether the effects on proliferation are from direct binding of the VDR or by conversion of inactive forms to active forms of vitamin $\mathrm{D}$ prior to binding, or a combination of the two. Chen et al. [17] showed that vitamin $\mathrm{D}_{3}$ at high concentration can directly interact with isolated VDR. In their study, the relative effectiveness of $1,25(\mathrm{OH})_{2} \mathrm{D}_{3}$ and $\mathrm{D}_{3}$ on cell proliferation in keratinocytes was compared to direct binding to VDR. They found that $\mathrm{D}_{3}$ inhibited proliferation at $10 \mathrm{nM}$ to $1 \mu \mathrm{M}$, while binding to VDR did not occur until $10 \mu \mathrm{M} .10 \mu \mathrm{M}$ is where we see effects of $D_{3}$ in thyroid cells. This would argue that our effects could in fact be due to direct binding to $\mathrm{D}_{3}$. It is important to note, however, that these experiments were conducted over a limited time period $(72 \mathrm{~h})$. It is possible that, with longterm continuous treatment, $\mathrm{D}_{3}$ may inhibit thyroid tumor growth in vivo.

Currently, there is no clear clinical association between serum $25(\mathrm{OH}) \mathrm{D}_{3}$ levels and thyroid cancer [18]. Various forms of $1,25(\mathrm{OH})_{2} \mathrm{D}_{3}$ have been used in clinical trials to treat different types of cancers, including prostate, colon and breast cancer [3], producing variable results. One potential explanation for the variability is there are different relative amounts of CYP24A1 within specific cancers and that cancers containing higher levels of CYP24A1 will not benefit from $1,25(\mathrm{OH})_{2} \mathrm{D}_{3}$ therapy. Several mechanisms exist to regulate the level of CYP24A1, one of which is post-transcriptional modification by micro RNA (miRNA). Low levels of miRNA125b result in higher levels of CYP24A1 [19]. Interestingly, significantly lower levels of miRNA125b have been found in anaplastic thyroid cancer compared to normal thyroid tissue [20]. It is plausible that the role vitamin $\mathrm{D}$ plays in cancer is not only related to baseline vitamin D, CYP27A1, CYP2R1, CYP27B1 and CYP24A1 levels, but also to baseline and stimulated CYP24A1
mRNA activity, an area of research that needs to be investigated more thoroughly. Variable CYP24A1 activity amongst different thyroid cancer cell lines would have implications on whether or not $1,25(\mathrm{OH})_{2} \mathrm{D}_{3}$ therapy would be beneficial.

Not all the thyroid cancer cells had increased expression of CYP24A1 when compared to the $\mathrm{N}$-thy cells. At this time, we do not have enough data to evaluate whether these differences can be due to differences in thyroid cancer cell types (i.e. papillary vs. follicular vs. anaplastic) alone, since the response within each histologic cell type was not similar. The largest response was in the TPC1 papillary and C643 anaplastic. These are very different histologically and clinically behave very differently, with papillary behaving much less aggressively than anaplastic. Consistent with their aggressiveness, TPC1 was also more sensitive to $1,25(\mathrm{OH}) 2 \mathrm{D}_{3}$ than C643. Interestingly, they were approximately equal in their response to $\mathrm{D}_{3}$ and $25(\mathrm{OH}) \mathrm{D}_{3}$. One possible explanation may be due to differences in genetic mutations (i.e. BRAF vs. RET vs. HRAS), given these were all distinct cell lines with different mutations. Anaplastic cell lines also had different mutations of origin. Hth7 cells have a known BRAF mutation, whereas C643 has an HRAS (G13R) mutation. Other potential explanations for differing response to vitamin $\mathrm{D}$ therapy could be the presence of VDR polymorphisms.

\section{Conclusions}

We report the presence of CYP27A1 and CYP2R1 mRNA expression in both cancerous and SV40 immortalized follicular cell lines, suggesting that thyroid cells may have the ability to locally produce active vitamin $\mathrm{D}$ from its precursor $\mathrm{D}_{3}$. The levels of CYP27A1, CYP2R1, CYP27B1 and CYP24A1 mRNA expression vary amongst different subtypes of thyroid cancer with different genetic mutations and respond differently to treatment with vitamin $\mathrm{D}_{3}$ and $1,25(\mathrm{OH})_{2} \mathrm{D}_{3}$. Gene expression of CYP27A1, CYP2R1 and CYP27B1 does not change significantly with treatment with $\mathrm{D}_{3}$ or $1,25(\mathrm{OH})_{2} \mathrm{D}_{3}$ compared to N-thy and any of the cell lines; however, TPC1 thyroid cancer cells have an increase in CYP24A1 mRNA levels in response to treatment with $1,25(\mathrm{OH})_{2} \mathrm{D}_{3}$ and $\mathrm{D}_{3}$, and $\mathrm{C} 643$ cells have an increase in CYP24A1 in response to $1,25(\mathrm{OH})_{2} \mathrm{D}_{3}$. Cell growth was inhibited by $\mathrm{D}_{3}, 25(\mathrm{OH})$ $\mathrm{D}_{3}$ and $1,25(\mathrm{OH})_{2} \mathrm{D}_{3}$ in both cell lines. TPC1 papillary cells were more sensitive to $1,25(\mathrm{OH})_{2} \mathrm{D}_{3}$ than C643 cells; however, they were similar in their response to both 
$25(\mathrm{OH}) \mathrm{D}_{3}$ and $\mathrm{D}_{3}$. Further studies evaluating protein expression, enzyme activity and binding of the VDR will be necessary to determine the true potential of any form of vitamin $\mathrm{D}$ as a thyroid cancer treatment.

\section{Acknowledgments}

Grant Support came from UNMC Department of Internal Medicine, Division of Diabetes, Endocrinology and Metabolism, Bly Memorial Research Fund and NIH P30 CA046934 to the University of Colorado Cancer Center. We wish to acknowledge re- search supported by the Department of Veterans Affairs and thank Dr. Rebecca Schweppe, University of Colorado, for sending all thyroid cancer cell lines and Dr. Robert Anderson, Omaha Veteran's Affairs Medical Center, for SV40-immortalized follicular cell lines (N-thy).

\section{Disclosure Statement}

None of the authors report a conflict of interest. The funders had no role in study design, data collection and analysis, decision to publish or preparation of the article.

\section{References}

1 Altekruse SF, Kosary CL, Krapcho M, Neyman N, Aminou R, Waldron W, et al: SEER Cancer Statistics Review, 1975-2007. Bethesda, National Cancer Institute. Available from: http://seer.cancer.gov/csr/1975-2007/.

-2 Nikiforova MN, Nikiforov YE: Molecular genetics of thyroid cancer: implications for diagnosis, treatment and prognosis. Expert Rev Mol Diagn 2008;8:83-95.

- 3 Deeb KK, Trump DL, Johnson CS: Vitamin D signalling pathways in cancer: potential for anticancer therapeutics. Nat Rev Cancer 2007;7:684-700.

-4 Hansen CM, Binderup L, Hamberg KJ, Carlberg C: Vitamin D and cancer: effects of $1,25(\mathrm{OH}) 2 \mathrm{D} 3$ and its analogs on growth control and tumorigenesis. Front Biosci 2001; 6:D820-D848

5 Prosser DE, Jones G: Enzymes involved in the activation and inactivation of vitamin D. Trends Biochem Sci 2004;29:664-673.

-6 Cheng JB, Levine MA, Bell NH, Mangelsdorf DJ, Russell DW: Genetic evidence that the human CYP2R1 enzyme is a key vitamin D 25-hydroxylase. Proc Natl Acad Sci USA 2004;101:7711-7715.

7 Cheng JB, Motola DL, Mangelsdorf DJ, Russell DW: De-orphanization of cytochrome P450 2R1: a microsomal vitamin D 25-hydroxilase. J Biol Chem 2003;278:3808438093.

8 Sharma V, Fretwell D, Crees Z, Kerege A, Klopper JP: Thyroid cancer resistance to vitamin $\mathrm{D}$ receptor activation is associated with 24-hydroxylase levels but not the ff FokI polymorphism. Thyroid 2010;20:1103-1111.
9 Khadzkou K, Buchwald P, Westin G, Dralle H, Akerstrom G, Hellman P: 25-hydroxyvitamin D3 1alpha-hydroxylase and vitamin D receptor expression in papillary thyroid carcinoma. J Histochem Cytochem 2006;54: 355-361.

10 Liu W, Asa SL, Fantus IG, Walfish PG, Ezzat S: Vitamin D arrests thyroid carcinoma cell growth and induces p27 dephosphorylation and accumulation through PTEN/akt-dependent and -independent pathways. Am J Pathol 2002;160:511-519.

11 Schweppe RE, Klopper JP, Korch C, Pugazhenthi U, Benezra M, Knauf JA, Fagin JA, Marlow LA, Copland JA, Smallridge RC, Haugen BR: Deoxyribonucleic acid profiling analysis of 40 human thyroid cancer cell lines reveals cross-contamination resulting in cell line redundancy and misidentification. J Clin Endocrinol Metab 2008;93:43314341.

12 Kramer C, Seltmann H, Seifert M, Tilgen W, Zouboulis CC, Reichrath J: Characterization of the vitamin $\mathrm{D}$ endocrine system in human sebocytes in vitro. J Steroid Biochem Mol Biol 2009;113:9-16.

13 Marchionatti AM, Picotto G, Narvaez CJ, Welsh J, Tolosa de Talamoni NG: Antiproliferativeaction of menadioneand 1,25(OH)2D3 on breast cancer cells. J Steroid Biochem Mol Biol 2009;113:227-232.

14 Tokar EJ, Webber MM: Cholecalciferol (vitamin D3) inhibits growth and invasion by up-regulating nuclear receptors and 25-hydroxylase (CYP27A1) in human prostate cancer cells. Clin Exp Metastasis 2005;22: 275-284.
15 Hamel FG, Fawcett J, Andersen CI, Berhanu P, Bennett RG, Duckworth WC: Insulin inhibition of protein degradation in cells expressing wild-type and mutant insulin receptors. J Endocrinol Invest 2003;26:10881094.

16 Sharma V, Fretwell D, Haugen B, Klopper JP: Vitamin D Receptor (VDR) Activation Decreases Thyroid Cancer Cell Growth and Is Enhanced by Inhibition of the Mitogen-Activated Protein Kinase (MAPK) Pathway (Abstract). American Thyroid Association Meeting, 2009.

17 Chen TC, Persons KS, Lu Z, Mathieu JS, Holick MF: An evaluation of the biologic activity and vitamin $D$ receptor binding affinity of the photoisomers of vitamin D3 and previtamin D3. J Nutr Biochem 2000;11:267272.

18 Laney N, Meza J, Lyden E, Erickson J, Treude $\mathrm{K}$, Goldner W: The prevalence of vitamin D deficiency is similar between thyroid nodule and thyroid cancer patients. Int J Endocrinol 2010;2010:805716.

19 Komagata S, Nakajima M, Takagi S, Mohri T, Taniya T, Yokoi T: Human CYP24 catalyzing the inactivation of calcitriol is post-transcriptionally regulated by miR-125b. Mol Pharmacol 2009;76:702-709.

20 Visone R, Pallante P, Vecchione A, Cirombella R, Ferracin M, Ferraro A, Volinia S, Coluzzi S, Leone V, Borbone E, Liu CG, Petrocca F, Troncone G, Calin GA, Scarpa A, Colato C, Tallini G, Santoro M, Croce CM, Fusco A: Specific microRNAs are downregulated in human thyroid anaplastic carcinomas. Oncogene 2007;26:7590-7595. 